HTTP://DX.DOI.ORG/10.12775/SZHF.2016.049

\author{
RAFA£ Michalski \\ Uniwersytet MikoŁaja Kopernika, Toruń, Polska \\ METABASIS1@WP.PL
}

\title{
Kant a rewolucja francuska - przyczynek do teorii politycznego entuzjazmu
}

Słowo wstępne

Niniejszy artykuł stanowi próbę wyeksplikowania pojęcia entuzjazmu politycznego, którym posługiwał się Immanuel Kant w Sporze fakultetów, wyrażając swój stosunek do rewolucji francuskiej. Entuzjazm towarzyszący reakcji neutralnych obserwatorów na to przełomowe w dziejach ludzkości wydarzenie odsyła, zdaniem filozofa, do ukrytego w nim sensu - nieprzedstawialnej idei wolności oraz obietnicy postępu ludzkiego gatunku. Entuzjazm jako czysto rozumowy afekt, a nie jako kolektywnie przeżywana, irracjonalna euforia, pełni w rozważaniach królewieckiego filozofa ważną heurystyczną funkcję. Pozwala mu bowiem uzasadnić pozytywne znaczenie rewolucji, która na poziomie empirycznych faktów okazała się godną moralnego potępienia eskalacją przemocy.

W artykule nie poprzestaniemy na samej rekonstrukcji pojęcia entuzjazmu, ale chcielibyśmy również zaryzykować nieco szerszą interpretację, w której pokażemy, że afekt ten daje się trafnie opisać dopiero w świetle kantowskiej teorii władzy sądzenia. Podejmując ten trop interpretacyjny, podążamy szlakiem wyznaczonym przez Hannah Arendt, zwłaszcza w jej Wykładach 
o filozofii politycznej Kanta ${ }^{1}$. Filozofka argumentuje tam, że Kant wprawdzie zajmował się w kilku znaczących tekstach filozofią polityki, jednakże nie wypracował żadnej systematycznej teorii polityki, a także - dodajmy - nigdzie nie przeanalizował struktury działania politycznego (problematykę działania podejmował wyłącznie w kontekście filozofii praktycznej, tj. w perspektywie moralnych decyzji jednostkowego podmiotu). Dlatego też nasze wywody rozpoczniemy od szkicowego określenia pojęcia polityki, które będzie przydatne $\mathrm{w}$ dalszej analizie kategorii entuzjazmu. Posłużymy się tutaj definicją zaproponowaną przez Arendt, zakładając, że nie popada ona w sprzeczność z ogólnym zamysłem filozofii politycznej Kanta (założenie to potwierdzi, jak sądzimy, rekonstrukcja kantowskiego pojęcia entuzjazmu w trzeciej części artykułu). Wyjdziemy zatem od określenia pojęcia polityki jako przestrzeni relacji międzyludzkich, w której realizuje się intersubiektywna wolność. W tym ujęciu uprawianie polityki opierałoby się na zdolności umiejętnego wykorzystania władzy sądzenia w celu realizowania i podtrzymywania wolności poszczególnych jednostek, jak i całej politycznej wspólnoty. W świetle takiej wykładni polityka potrzebuje władzy sądzenia jako „członu pośredniego”, łączącego i umożliwiającego przejście od teorii do praktyki. Dlatego w pierwszej części artykułu siłą rzeczy omówimy również problematykę „sądzenia”, ale tylko $\mathrm{w}$ takim zakresie, $\mathrm{w}$ jakim okaże się ona przydatna do lepszego uchwycenia sensu pojęcia entuzjazmu. W drugiej części podejmiemy próbę wyjaśnienia dwuznacznej postawy Kanta wobec rewolucji francuskiej. Filozof bowiem z perspektywy moralnej jednoznacznie ją potępia, a z perspektywy estetyczno-politycznej - ocenia bardzo pochlebnie. Kluczem do zrozumienia tej ambiwalencji będzie kategoria jawnej publiczności (Publizität). W trzeciej części przejdziemy natomiast do głównego tematu artykułu, tj. do eksplikacji pojęcia entuzjazmu. Pokażemy tutaj, że Kant opisuje za pomocą tego pojęcia proces konstytuowania się sfery politycznej jako quasi-teatralnej przestrzeni publicznej. Ogarnięta entuzjazmem, niezaangażowana w konkretne działania widownia "rewolucyjnego spektaklu” tworzy bowiem, jego zdaniem, wymiar publicznej debaty, w której kluczową rolę odgrywa władza sądzenia, a ściślej specyficzny typ sądów określonych przez nas (na potrzeby artykułu) mianem „sądów entuzjastycznych”. W debacie tej najważniejsza jest nie tyle determinująca władza sądzenia, która próbowałaby wyjaśnić rewolucję w kategoriach przyczynowości przez odwołanie się do ustalonych prawideł

${ }^{1}$ H. Arendt, Wykłady o filozofii politycznej Kanta, tłum. R. Kuczyński, M. Moskalewicz, Warszawa 2012. 
i akceptowanych powszechnie teorii, ile refleksywna umiejętność dostrzegania „przebłysku idei” czy „znaku dziejowego” w gmatwaninie empirycznych faktów. To zaś zbliża entuzjastyczną deliberację do sfery sądów estetycznych, które bez pośrednictwa zdefiniowanych pojęć zgłaszają roszczenia do swojej powszechności. Wykorzystując wskazane podobieństwo, spróbujemy w końcowej części artykułu doprecyzować strukturę „entuzjastycznego sądu”, a następnie pokażemy, że entuzjazm odgrywa istotną rolę nie tylko po stronie "oświeconej widowni”, ale również wśród zaangażowanych rewolucjonistów.

\section{Władza sądzenia a polityka}

Jak już wspomnieliśmy, Kant nie wypracował systematycznej teorii polityki, nie podał również nigdzie jej definicji. Takie teksty jak Metafizyka moralności, czy Ku wieczystemu pokojowi pokazują jednoznacznie, że działalność polityczna może rozgrywać się jedynie w sferze wyznaczonej przez normy prawa, a zatem nie może naruszać pod żadnym pozorem porządku prawno-ustrojowego opartego na konstytucji. Polityka, w przeciwieństwie do moralności, służy powszechnemu dobrostanowi i powinna zapewniać pokojowe współżycie jednostek i państw. Polityka to jednak również przestrzeń realizowania wolności, o czym filozof pisze między innymi w Sporze fakultetów przy okazji rozważania sensu rewolucji francuskiej. Właśnie to przekonanie Kanta o ścisłym powiązaniu polityki i wolności pozwala nam nawiązać do analogicznego rozumienia polityki, które zaproponowała Hannah Arendt, a które okaże się pomocne w naszej interpretacji pojęcia entuzjazmu.

Według autorki Kondycji ludzkiej życie poświęcone sprawom polityki daje człowiekowi możliwość realizowania wolności oraz nadawania sensu własnej egzystencji, który urzeczywistnia się w sferze intersubiektywnych relacji i zbiorowej pamięci. Bios politicos wyrywa jednostkę z wąskiego kręgu partykularnych interesów i umieszcza ją w obszarze tego, co wspólne (koinon), czyli w sferze publicznej. Polityka $z$ istoty wolna od przemocy (przedpolitycznego sposobu radzenia sobie $z$ życiowymi koniecznościami), opiera się na działaniu i mowie (praxis i lexis), które w pierwszym rzędzie nastawione są na realizację dobra ogółu, a nie na instrumentalne osiąganie subiektywnych celów ${ }^{2}$. Polityka stanowi dla Arendt dziedzinę wielości i unikalnej odmien-

\footnotetext{
2 Por. H. Arendt, Kondycja ludzka, przeł. A. Łagodzka, Warszawa 2000, s. 27-32, 56-64.
} 
ności jednostek, zakłada nieuchronnie równoczesność niezliczonych, pojedynczych perspektyw, dla których nie da się znaleźć wspólnej miary. Dlatego też sąd polityczny różni się radykalnie od sądu poznawczego. Żaden polityk nie dysponuje (i nie może dysponować) obiektywną, niezawodną wiedzą o tym, jak postępować, ale musi podejmować decyzje. Polityka potrzebuje więc zaangażowania, zdolności do podejmowania szybkich decyzji, do praktycznej realizacji ustalonych celów, która powinna ostatecznie opierać się na rozumnych racjach, na trzeźwej ocenie sytuacji i racjonalnym przewidywaniu skutków, nawet jeśli logiczna kalkulacja musi w pewnym momencie ustąpić irracjonalnemu fiat woli podmiotów zaangażowanych w rozwiązywanie konkretnych problemów. Chcąc działać, polityk musi bowiem - prędzej czy później - zdać się na irracjonalną decyzję przerwania - teoretycznie nieskończonego - procesu deliberacji, roztrząsania przesłanek przemawiających za lub przeciw określonej postawie. Wskazana powyżej „niewywiedlność” działania politycznego $\mathrm{z}$ racjonalnie uzasadnionych przesłanek, która wiąże się $\mathrm{z}$ tym, że podejmując ważne, nietypowe decyzje, nigdy nie jesteśmy w stanie opisać całości naszych motywacji, ani przewidzieć ich skutków, skłania filozofkę do uznania politycznej praxis za akt otwierania czy inicjowania nowego, nieprzewidywalnego łańcucha zdarzeń. W Kondycji ludzkiej znajdujemy następujące określenie działania:

Działać w najogólniejszym sensie, znaczy przedsiębrać coś nowego, rozpoczynać (jak wskazuje greckie słowo archein, „rozpoczynać”, „prowadzić”, wreszcie „rządzić), wprawiać coś w ruch (co jest pierwotnym znaczeniem ludzkiego agere). Ludzie są initium, nowymi przybyszami, którzy dają czemuś początek na mocy samych swoich narodzin, dlatego podejmują się czegoś nowego i skłonni są do działania ${ }^{3}$.

Polityka stanowi zatem dla Arendt obszar konstytuowania się ludzkiej wolności w wymiarze intersubiektywnym. Jej głównym „narzędziem” jest działanie zespolone z mową, ze zdolnością do wydawania sądów, które mają refleksywny charakter w tym sensie, że nie kierują się ustalonymi regułami, lecz same wyprowadzają ogólne prawidła postępowania z tego, co szczegółowe. Polityczna praxis w przeciwieństwie do przewidywalnego, rutynowego zachowania otwiera przed działającym perspektywę nowości, wymaga więc odwagi - cnoty politycznej par excellence.

3 Tamże, s. 195. 
Wskazane powyżej elementy sformułowanego przez Arendt pojęcia polityki będą istotne dla naszej interpretacji entuzjazmu. Rewolucja francuska stanowi bowiem paradygmatyczny przypadek działania politycznego. Burząc stary porządek, nie tylko wyrywa ona rewolucjonistów z wygodnych okowów prywatnego życia i kieruje ich intencje ku uniwersalnej idei wolności, ale również inicjuje niepowtarzalne novum, jednorazowe, niepowtarzalne „wydarzenie” w sferze „ludzkich spraw”, którego skutkiem są radykalne zmiany ustrojowe. Rewolucja, mimo wpisanej w nią irracjonalności, wytwarza polityczną sferę publiczną - światłą publiczność, jak pisze Kant, która nadaje temu wydarzeniu sens wykraczający poza partykularne motywacje i wyobrażenia samych rewolucjonistów. Innymi słowy, rewolucja pozbawiona entuzjastycznie reagującej i deliberującej „,widowni” nie przekroczyłaby progu polityczności, pozostając przejawem „nagiej”, irracjonalnej przemocy. Dopiero $\mathrm{w}$ połączeniu $\mathrm{z}$ wydającą (o)sąd publicznością rewolucja staje się wydarzeniem politycznym sensu stricte. Dlatego też dla zrozumienia polityki w ogólności, a rewolucji francuskiej w szczególności, należałoby - w przyjętej przez nas perspektywie interpretacyjnej - przyjrzeć się bliżej naturze władzy sądzenia w jej funkcji refleksywnej.

Według Kanta przedmiotem sądu refleksywnego jest to, co szczegółowe (np. pewien fakt naturalny, własność estetyczna czy wydarzenie historyczne). Jak pisze Kant, sąd staje się refleksywny, gdy „[...] dane jest tylko to, co szczegółowe, a do czego władza sądzenia znaleźć ma to, co ogólne [...]”, natomiast „[...] gdy dane jest to, co ogólne (reguła, podstawowa zasada [Princip], prawo), to władza sądzenia, która subsumuje pod nie to, co szczegółowe, jest determinująca”" Polityka zmagająca się z przygodnością zjawisk społecznych może oczywiście posługiwać się jedynie refleksywną władzą sądzenia, ponieważ nie dysponuje żadnymi ogólnymi regułami, które w wiążący sposób wyjaśniałyby procesy polityczne. Istotne przy tym jest również to, że władza sądzenia nie orzeka w sprawach moralnych, ponieważ moralność to obszar zarezerwowany dla rozumu. Stanowi natomiast znakomitą okazję do przejścia od trudnej problematyki moralnej do spraw związanych z życiem codziennym i polityką. Życie domaga się bowiem dopełnienia w postaci sądu smaku, który poddaje ocenie pojedyncze, zawsze konkretne przypadki. Este-

\footnotetext{
${ }^{4}$ I. Kant, Krytyka władzy sądzenia, t. IV, s. 40. Wszystkie odnośniki do pism Kanta - jeżeli nie zaznaczono inaczej - odsyłają do wydania: I. Kant, Dzieła zebrane, Wydanie Translatorium Filozofii Niemieckiej Instytutu Filozofii UMK, t. 1-6, Toruń: Wydawnictwo Naukowe Uniwersytetu Mikołaja Kopernika 2010-2014. Po tytule dzieła (lub jego skrócie) podawana jest tylko paginacja, w której cyfra rzymska oznacza numer tomu, a cyfra arabska numer strony.
} 
tyka w nie mniejszym stopniu niż polityka, jest obszarem wydawania sądów - ocen i decyzji na temat otaczających człowieka przedmiotów. Smak zastosowany w obydwu dziedzinach przesądza w znacznej mierze, jak jawi się nam rzeczywistość. W pewnym sensie jest on również kryterium bycia rozumnym człowiekiem. Umiejętność wydawania sądów sprowadza się bowiem do zdolności czynienia siebie zrozumiałym i przekonującym. W przeciwieństwie do szaleńca człowiek rozumny potrafi komunikować, prezentować własne opinie, z którymi można polemizować, nie zgadzać się, które jednak odsyłają do wspólnego horyzontu rozumienia. Ów wspólny horyzont wyznaczają nie tylko pojęcia, ale również pewien rodzaj uczuć jak choćby bezinteresowne odczucie upodobania w pięknie, które zawiera w sobie roszczenie do powszechności, a zatem pośrednio odsyła do całego gatunku ludzkiego. Kant, opisując czwarty moment sądu o pięknie, czyli modalność koniecznego upodobania, stwierdza:

Przez sensus communis należy jednak rozumieć ideę zmysłu wspólnego [eines gemeinschaftlichen Sinnes], tzn. taką władzę osądzania [Beurtheilungsvermogen], która w swym refleksie uwzględnia w myślach (a priori) sposób przedstawiania właściwy dla każdego innego człowieka po to, by poniekąd swój sąd utrzymać w granicach całokształtu ludzkiego rozumu unikając przez to złudzeń [wypływających] z podmiotowych warunków, indywidualnych, które mogłyby być uznane $\mathrm{z}$ obiektywne, wywierając ujemny wpływ na sąd ${ }^{5}$.

Uczestnictwo we wspólnym zmyśle nie jest więc czymś danym z góry, lecz wymaga treningu wyobraźni, ćwiczenia refleksu, tj. zdolności do odzwierciedlania w myślach pozycji innych, choć powiązanych ze mną nicią rozumności podmiotów. Konieczność szkolenia smaku jeszcze wyraźniej dochodzi do głosu w określeniu drugiego momentu sądu estetycznego (momentu ilości), zgodnie z którym piękne jest to, co podoba się powszechnie bez pośrednictwa pojęć. Wprawdzie Kant podkreśla tutaj, że sąd smaku nie ma podstawy w postaci ogólnych praw, determinujących reguł, jednakże w tej mierze, w jakiej jest refleksywny, pozwala się wyartykułować również pojęciowo i dyskutować w ramach estetycznego dyskursu, a zatem w ramach języka, który wprawdzie zgłasza roszczenia do uniwersalności, ale nie dysponuje konceptualnym środkami determinującej władzy sądzenia. W argumentacji Kanta pojawia się zatem odwołanie do bezapelacyjności „prawdy uczucia”, która w żadnym wypadku (sądu estetycznego) nie może bazować na intelekcie czy

${ }^{5}$ Tamże, s. $169-170$. 
rozumie. Z drugiej strony, Kant stwierdza jednak, że niekorzystny dla nas sąd innych osób może skłonić nas niekiedy do rewizji pierwszego sądu, jeżeli ponownie rozpatrzymy dany przypadek $\mathrm{w}$ świetle innych argumentów. To więc, co uważa się za „zmysłową oczywistość”, jest zawsze współokreślane przez kontekst refleksji, która uwzględnia intersubiektywność dyskursu, dopuszcza polemikę, weryfikację i korektę sądu. W tym kontekście osobliwość sądu smaku polega na tym, że pośredniczy on pomiędzy „niemą” bezpośredniością odczucia a siłą perswazji abstrakcyjnych konstrukcji pojęciowych. Kant próbuje wyjaśnić tę osobliwość, wskazując trzy maksymy „pospolitego ludzkiego rozsądku”, które kształtują sąd estetyczny: „1) myśleć samemu [Selbstdenken], 2) myśleć stawiając się w miejsce każdego innego człowieka, 3) myśleć, pozostając zawsze w zgodzie z samym sobą"6. W odniesieniu do polityki najważniejsza wydaje się druga maksyma „myślenia rozszerzającego", która odsyła do antropologicznego warunku władzy sądzenia, to znaczy, do towarzyskości (Geselligkeit) „będącej w powołaniu człowieka celem najwyższym" " czyli faktu, że ludzie zależą od siebie nie tylko ze względu na swoją cielesność i potrzeby fizyczne, lecz właśnie z uwagi na swoje zdolności umysłowe, które mają istotne znaczenie nie tylko w dziedzinie poznania czy moralności, ale również w polityce. Myślenie rozszerzające polega na tym - jak pisze Kant - by „[...] wznieść się ponad podmiotowe, indywidualne warunki [subjective Privatbedingungen] sądu (gdy liczni inni pozostają przez nie ograniczeni) i rozważać swój własny sąd z powszechnego punktu widzenia (które może on określić tylko dzięki temu, że wczuwa się w stanowisko innych)". Innymi słowy, polega ono na przełamaniu własnej egocentrycznej perspektywy, na umiejętności umieszczania siebie w pozycji innych ludzi, na paradoksalnym przedstawianiu samemu sobie siebie jako innego, a zarazem tego samego (tj. istoty racjonalnej). Dzięki myśleniu rozszerzającemu wznosimy się ponad partykularne interesy i uzyskujemy bezstronny „powszechny punkt widzenia” - nasza wyobraźnia staje się wówczas sceną, na której występujemy wobec widowni całej ludzkości ${ }^{9}$. Usytuowanie podmiotu w pozy-

\footnotetext{
6 Tamże, s. 170.

${ }^{7}$ I. Kant, Przypuszczalny początek ludzkiej historii, t. VI, s. 120

${ }^{8}$ I. Kant, Krytyka władzy sądzenia..., dz. cyt., s. 171.

${ }^{9}$ Opieramy się tutaj na interpretacji Arendt, dla której wspomniana możliwość przejmowania różnych punktów widzenia wyraża właściwy sens pluralizmu politycznego, który tworzy przestrzeń wolności dla słów i czynów. W eseju Prawda i polityka filozofka pisze, że proces imaginatywnej reprezentacji innych punktów widzenia „[...] nie polega na ślepym przyjmowaniu poglądów tych, którzy sytuują się gdzieś indziej i spoglądają na świat z innej
} 
cji bezstronnego widza pozwala ogarnąć całość skomplikowanych powiązań między faktami, uchwycić sens ambiwalentnych wydarzeń (na przykład rewolucji francuskiej), a tym samym daje istotną przewagę niezaangażowanemu obserwatorowi nad uczestnikiem tych zdarzeń, który jest ograniczony zakresem roli, jaką przyszło mu w nich odegrać.

Dotąd podążaliśmy tropem interpretacyjnym wyznaczonym przez Arendt w Wykładach o filozofii politycznej Kanta, w dalszej części artykułu spróbujemy natomiast poszerzyć jej wykładnię o problematykę związaną z pojęciem entuzjazmu. Pokażemy mianowicie, że filozofia Kanta dostarcza jeszcze jednej interesującej i płodnej teoretycznie perspektywy rozumienia polityki, której nie dostrzegła filozofka. W tym celu dokonamy dość przewrotnego zabiegu interpretacyjnego, który pozwoli nam wykazać, że dokładnie w tym miejscu, gdzie na pierwszy rzut oka wydawałoby, iż Kant myśli w zgodzie z Arendt, rzecz ma się zgoła przeciwnie. Otóż dla autorki Korzeni totalitaryzmu główną przyczyną niepowodzenia rewolucji francuskiej było włączenie emocji do sfery politycznej. Gdy żyrondystom nie udało się stworzyć konstytucji i ustanowić rządu republikańskiego, a zatem gdy jakobini pod przywództwem Robespierra przejęli władzę i przestali interesować się formami ustrojowymi, imperatyw współczucia z uciśnionym ludem urósł do rangi najważniejszej cnoty politycznej. Według Arendt współczucie przekształcone w bezosobową litość, w instrument politycznej agitacji niepostrzeżenie otworzyło śluzy dla nieokiełznanych żywiołów przemocy i zbiorowej agresji, doprowadziło zatem do ostatecznego upadku rewolucji. Czyż Kant nie zgodziłby się z taką diagnozą klęski rewolucji, a przynajmniej z ogólną tezą, że afekty mają destrukcyjny wpływ na wszelkie racjonalne działanie? Przywołajmy tylko jeden z wielu ustępów, w których królewiecki filozof wyraża swoją postawę wobec natury emocji: „Podporządkowanie się afektom i namiętnościom jest zapewne zawsze chorobą umysłu, gdyż oba stany wykluczają panowanie rozumu"10.

perspektywy; nie chodzi tu ani o empatię [...], ani o liczenie głosów i przyłączanie się do większości, lecz o to, aby przy zachowaniu własnej tożsamości być tam, gdzie mnie nie ma, to znaczy myśleć inaczej niż nakazuje mi to mój własny pogląd. Im więcej stanowisk innych ludzi przedstawiam sobie w umyśle, rozważając daną kwestię, i im lepiej mogę wyobrazić sobie, co czułabym i myślała, gdybym była na ich miejscu, tym silniejsza będzie moja zdolność do myślenia reprezentującego i tym bardziej prawomocne będą moje ostateczne wnioski, moja opinia., [w:] H. Arendt, Prawda i polityka, [w:] tenże, Między czasem minionym i przyszłym, tłum. M. Godyń, W. Madej, Warszawa 1994, s. 283-284.

${ }^{10}$ I. Kant, Antropologia w ujęciu pragmatycznym, tłum. E. Drzazgowska, P. Sosnowska, Warszawa 2005, s. 194. 
A jednak w Sporze fakultetów odnajdujemy pozytywną ocenę afektu entuzjazmu, który stanowi dla Kanta nieodłączny element konstruktywnej polityki. Uzasadnienie tej interpretacji przyniesie trzecia część tego artykułu, wcześniej, w drugiej części spróbujemy natomiast wstępnie wyjaśnić dwuznaczność jego oceny rewolucji, wskazując na kluczowe znaczenie kategorii jawności publicznej w zarysowanym przez niego „projekcie oświecenia”.

\section{Rewolucja jako przekleństwo i obietnica wolności}

Stosunek Kanta do rewolucji francuskiej był niewątpliwie ambiwalentny, obok postawy graniczącego z entuzjazmem uznania dla „ostatniego wielkiego wydarzenia" odnajdujemy bowiem w jego pismach zdecydowane potępienie wydarzeń rewolucyjnych i skrajnie - wydawałoby się - legalistyczną krytykę wszelkich form protestu, buntu, nieposłuszeństwa obywatelskiego, które naruszają panujący porządek prawny. Filozof używa w tym kontekście trzech argumentów. Pierwszy pojawia się w rozprawce O porzekadle: To może być stuszne $w$ teorii, ale nic nie jest warte $w$ praktyce. Nazwijmy go argumentem przeciwko eudajmonizmowi. Dotyczy on sytuacji, w której jakiś naród próbuje obalić dany porządek władzy, kierując się głównie pragnieniem poprawy swojego dobrostanu. Rebelianci chcą zmiany ustroju, ponieważ obecny system nie zapewnia im w wystarczającym stopniu poczucia szczęścia. Według Kanta taka motywacja jest nie tylko zwodnicza (choćby ze względu na to, że wyobrażenia szczęśliwego życia podlegają nieustannym zmianom i z natury są nieokreślone), ale przede wszystkim jest destrukcyjna dla porządku prawa, który powinien opierać się na powszechnym prawie rozumowym, a nie na kapryśnych skłonnościach.

Jeśli zatem naród może z największym prawdopodobieństwem stwierdzić, że przy pewnym funkcjonującym właśnie prawodawstwie utraci on swe szczęście, to co powinien robić? Czy nie powinien przeciwstawić się? Odpowiedź może być tylko jedna: nie pozostaje mu nic innego, aniżeli być posłusznym. Bo chodzi tu nie o szczęśliwość, której poddany może oczekiwać w związku z pewnymi ustaleniami, czy też z pewnym zarząazaniem wspólnotą, lecz przede wszystkim o prawo [Recht], które tym samym powinno być zabezpieczone dla wszystkich; 
prawo jest najwyższą zasadą, z której powinny wywodzić się wszystkie maksymy dotyczące wspólnoty i która nie jest ograniczona przez żadną innąą ${ }^{11}$.

Dzieje się tak, ponieważ władza zwierzchnia nie służy pomnażaniu jednostkowego czy zbiorowego szczęścia obywateli, lecz obronie porządku prawnego, który mimo swoich ograniczeń i wad stanowi jedyną rękojmię tego, że możemy realizować się jako moralne podmioty obdarzone indywidualną wolnością. Jeśli zniszczymy panujący ustrój polityczny i fundujące go prawo w imię poprawy warunków życia, to utracimy zarazem możliwość ukonstytuowania nowego lepszego porządku prawnego. Nie da się bowiem utworzyć spójnego prawa, opierając się na roszczeniach socjalnych. Idealny, $\mathrm{w}$ pełni sprawiedliwy system prawny, gdyby mógł kiedykolwiek zaistnieć, zrównałby prawo z moralnością, znosząc konieczność stosowania zewnętrznego przymusu. Jak pisze Kant w Metafizyce moralności: „Prawo takie zawsze jest jednak tylko ideą, której realizacja ogranicza się do skoordynowania jej środków z moralnością, której naród nie ma prawa naruszyć. Tego nie można zaś dokonać na drodze rewolucji, która zawsze jest niesprawiedliwa"12. Legalizm Kanta nie wynika z ślepej apoteozy panującego status quo, lecz raczej z trzeźwego, pragmatycznego rozpoznania nieuchronnej niedoskonałości wpisanej w każdy realnie istniejący system prawno-polityczny. Filozof żywi wprawdzie nadzieję, że ludzkość może w swoim rozwoju zbliżać się do idei państwa celów (czyli państwa, w którym wszyscy postępują zgodnie z imperatywem kategorycznym), ale zarazem doskonale zdaje sobie $z$ tego sprawę, że wcale tak być nie musi. Podkreśla przy tym, że uzasadnieniem prawa nie mogą być względy moralne, gdyż prawo nie służy doskonaleniu moralnemu, choć mu niekiedy sprzyja, lecz dba jedynie o to, aby obowiązujących przepisów przestrzegali zarówno ludzie cnotliwi, jak nikczemni.

Drugi argument (nazwijmy go argumentem przeciwko regresowi) łączy się bezpośrednio z pierwszym i dotyczy nieuchronnego skutku każdej rewolucji, jakim jest regres do stanu natury. Wreszcie trzeci, „logiczny argument” wskazuje na wewnętrzną sprzeczność, jaka kryje się w każdej próbie zniesienia panującego ustroju:

Tak zatem lud nie może zgodnie z prawem stawiać oporu ustawodawczej władzy w państwie; bowiem jedynie podporządkowanie się powszechnej woli usta-

${ }^{11}$ I. Kant, O porzekadle: To może być stuszne $w$ teorii, ale nic nie jest warte w praktyce, t. VI, s. $288-289$.

${ }^{12}$ I. Kant, Metafizyka moralności, t. V, s. 262. 
wodawczej czyni możliwym stan prawny. Lud nie ma zatem prawa do buntu (seditio) ani tym bardziej do rebelii (rebellio), a już w żadnym razie prawa do tego, aby występując przeciwko pojedynczej osobie (osobie monarchy) pod pretekstem nadużywania przez niego swej władzy (tyrannis) targnąć się na jego osobę, czy nawet na jego życie (monarchomachismus sub specie tyrannicidii). Wszelka próba podjęta w tym celu jest zdradą stanu (proditio eminens), a tego rodzaju zdrajca jako ktoś, kto usiłuje zgubić swą ojczyznę (parricida), nie zasługuje na inną karę niż na karę śmierci' ${ }^{13}$.

Lud nie może posiadać prawa do buntu, ponieważ jest ono sprzeczne nie tylko z samym prawem, ale i ze zdrowym rozsądkiem. Bunt podkopuje porządek prawny, sprzyja przemocy, przede wszystkim zaś niszczy konstytucję stanowiącą fundament umowy społecznej. Gdyby konstytucja dopuszczała prawo do buntu, potrzebny byłby kolejny, ponadkonstytucyjny organ, który by o tym decydował. To jednak rodzi błędne koło ${ }^{14}$.

Tym samym Kant zdecydowanie potępia rewolucję i oręduje za zmianą przeprowadzoną na drodze reform i to nie tyle władzy ustawodawczej, lecz tylko wykonawczej, a zatem $\mathrm{w}$ ramach konstytucjonalnie zabezpieczonego porządku prawa.

Mądrość państwowa w obecnym stanie rzeczy będzie więc uważać za swój obowiązek przeprowadzenie reform, odpowiadających ideałowi prawa publicznego; natomiast rewolucji, do których doprowadziła sama natura, nie będzie traktować jako parawanu dla jeszcze większego ucisku, lecz jako wołanie natury, by poprzez gruntowne reformy urzeczywistniony został ustrój prawny, oparty na zasadach wolności, jedyny trwały i sprawiedliwy. ${ }^{15}$

\footnotetext{
${ }^{13}$ I. Kant, Spór fakultetów, t. V, s. 421-422.

${ }^{14}$ „Powodem, dla którego lud ma obowiązek znosić nawet takie nadużycia najwyższej władzy, które wydają się nie do zniesienia, jest to, że jego opór stawiany najwyższej instancji prawodawczej nie daje się nigdy pomyśleć inaczej niż jako sprzeczny z prawem, a nawet wywracający cały prawny porządek. Ażeby bowiem był on uprawniony, musiałaby istnieć publiczna norma zezwalająca na ten opór ludu. Najwyższe ustawodawstwo zawierałoby zatem klauzulę, że nie jest najwyższe, i w tym samym sądzie czyniło lud władcą tego, komu jest on poddany, co jest wewnętrzną sprzecznością. Ta sprzeczność rzuci się nam w oczy, gdy tylko zadamy pytanie, kto miałby być sędzią w tym sporze między ludem i władcą (gdyż z punktu widzenia prawa są to zawsze dwie różne osoby moralne). Widać bowiem jasno, że lud chce być sędzią w swojej własnej sprawie. Zmiany (wadliwego) ustroju państwowego, która niekiedy jest niewątpliwie potrzebna, może zatem dokonać jedynie sam władca przez reformę, nie zaś lud przez rewolucję." Tamże, s. 423.

${ }^{15}$ I. Kant, Ku wieczystemu pokojowi, t. VI, s. 361.
} 
Kluczową rolę $\mathrm{w}$ reformach prawno-politycznych odgrywać powinna, zdaniem Kanta, oświecona publiczność, ponieważ najważniejszą wolnością polityczną jest dla niego wolność wypowiedzi i druku, mianowicie wolność, „[...] by czynić ze swego rozumu publiczny użytek w każdej sytuacji”"16. To właśnie zasada jawności publicznej (Publizität) myślenia i działania decyduje o pomyślności zmian wprowadzanych w panującym porządku władzy i gwarantuje zgodność polityki z moralnością. Publiczne rozprawianie stanowi w pewnym sensie metodę oświecenia, czyli stopniowego wydobywania się ze stanu zawinionej przez siebie niedojrzałości. Jak pisze Kant w swojej słynnej rozprawce:

Niedojrzałość jest nieumiejętnością w posługiwaniu się własnym rozumem bez przewodnictwa innych. Niedojrzałość ta jest zawiniona przez człowieka, jeśli jej powód tkwi nie w braku rozumu, ale zdecydowania i odwagi, by swym rozumem posługiwać się bez zwierzchnictwa innych ${ }^{17}$.

Oświecenie przebiega zarówno na planie jednostkowym (dążenie do całkowitej samodzielności w myśleniu), jak i na poziomie gatunkowym, obejmującym całą ludzkość (dążenie w kierunku porządku doskonale sprawiedliwego). W obydwu wymiarach wymaga ono pośrednictwa ze strony publiczności - rozprawiającego świata czytających i krytycznie myślących podmiotów.

Stąd też każdemu człowiekowi z osobna ciężko samodzielnie wyswobodzić się z wrodzonej niemal niedojrzałości [...] Mimo to jest jednak możliwe, ażeby publiczność sama się oświeciła. Jeśli tylko pozostawić jej wolność, jest to niemalże nieuniknione, ponieważ nawet pośród mianowanych opiekunów wielkiego tłumu zawsze znajdzie się kilku myślących samodzielnie, którzy po zrzuceniu jarzma niedojrzałości będą wokół siebie upowszechniać ducha rozumowej oceny własnej wartości i powołania każdego człowieka do samodzielnego myślenia ${ }^{18}$.

Samodzielne myślenie jest dla Kanta w pełni zbieżne z czynieniem zeń użytku publicznego:

\footnotetext{
${ }^{16}$ I. Kant, Odpowiedź na pytanie: czym jest oświecenie?, t. VI, s. 48.

17 Tamże, s. 47.

${ }^{18}$ Tamże.
} 
Wprawdzie powiada się, że swoboda wypowiadania się albo pisania mogłaby nam zostać odebrana przez zwierzchnią władzę, chociaż nie może ona tego uczynić z wolnością myślenia. Jednakże [zapytajmy], jak wiele i jak trafnie zdołalibyśmy myśleć, gdybyśmy nie czynili tego poniekąd wspólnie z innymi ludźmi, którym udzielalibyśmy własnych myśli [otrzymując w zamian] ich myśli! ${ }^{19}$

Również Arendt podkreśla, że wolność słowa, postulat czynienia publicznego użytku z rozumu i zasada publicznej jawności wyznaczają istotne współrzędne kantowskiego projektu oświecenia, jednakże filozofka wydaje się iść za daleko w swojej interpretacji, gdy stwierdza, że zniesienie wolności "pióra i opinii" jest dla Kanta odpowiednim momentem do wzniecenia bun$\mathrm{tu}^{20}$. Nie znajdujemy bowiem w tekstach królewieckiego filozofa ustępów, które potwierdzałyby tę skądinąd interesującą wykładnię, a przedstawiona przez nas krytyka nieposłuszeństwa obywatelskiego opartego na przemocy jednoznacznie ją obala.

Kant potępia zatem bunt wobec władzy, wszelką rewolucję i stawia na oświecającą moc deliberującej publiczności. Oświecenie jest według niego, podobnie jak dla encyklopedystów, przede wszystkim zadaniem uczonych, a pośród nich zwłaszcza tych, którzy mają do czynienia z zasadami czystego rozumu, czyli filozofów. Opisywany przez niego spór fakultetów toczy się w formie krytycznej dyskusji fakultetów niższych z wyższymi. Te drugie, a mianowicie teologia, prawoznawstwo i medycyna opierają się na autorytecie i są nadzorowane przez państwo, ponieważ kształcą uczonych specjalistów - duchownych, sędziów i lekarzy. Natomiast fakultety niższe mają do czynienia nie tyle z samą nauką, ile z poznaniem uzyskiwanym za pomocą czystego rozumu. Ich przedstawiciele, filozofowie, kierują się - niezależnie od interesu władz - tylko względami rozumu. Powołaniem fakultetu filozoficznego jest „publiczne głoszenie prawdy”21. W takim sporze fakultetów rozum musi „[...] być w prawie głosić publicznie, bo bez takiej swobody prawda (ze szkodą dla samego rządu) nigdy nie zostanie ujawniona"22. Jednakże dziedzina publicznego, oświecającego rozprawiania, w której filozofowie uprawiają swoje rzemiosło, nie jest sferą wyłącznie akademicką, choć jej głównym ośrodkiem jest akademia. Na audytorium, przed którym toczy się dyskusja filozofów, „zasiada” zarówno rząd, który pragną oni pouczyć i przeegzamino-

\footnotetext{
${ }^{19}$ I. Kant, Co oznacza: orientować się w myśleniu?, t. VI, s. 152.

${ }^{20}$ H. Arendt, Wykłady o filozofii..., dz. cyt., s. 89.

${ }^{21}$ I. Kant, Spór fakultetów..., dz. cyt., s. 216.

22 Tamże, s. 203.
} 
wać, jak i szeroka publiczność - „lud”, który pragną wdrożyć w proces oświecenia, przyuczyć do samodzielnego i krytycznego posługiwania się własnym rozumem. Dzieło oświecenia nie jest zatem dla Kanta zastrzeżone wyłącznie dla filozofa, ale może być udziałem każdego, kto potrafi uczynić publiczny użytek ze swego rozumu. Spór fakultetów stanowi zatem rodzaj punktu zapalnego, z którego rozchodzi się na coraz szersze kręgi „płomień oświecenia”. W rozprawce Odpowiedź na pytanie: czym jest oświecenie? Kant stwierdza:

Za publiczny użytek swego własnego rozumu uznaję takie jego zastosowanie, jakie wobec całej publiczności wykształconego świata [Leserwelt] czyni z niego ktoś, [występując] jako uczony. Osobistym użytkiem nazywam taki, jaki wolno [człowiekowi] czynić ze swego rozumu na pewnym powierzonym mu publicznym stanowisku czy urzędzie. Oczywiście w takim przypadku zastanawianie się nie jest dozwolone, tu raczej trzeba być posłusznym. Dopóki jednak ten element mechanizmu traktuje się równocześnie jako część pewnej stanowiącej całość społeczności, a nawet wspólnoty światowej, a zatem jako uczonego, który za pośrednictwem swych pism zwraca się do publiczności we właściwym znaczeniu tego słowa, to ten może z pewnością zastanawiać się ${ }^{23}$.

W ujęciu Kanta zasadniczo każdy człowiek powołany jest do tego, by stać się rzecznikiem czystego rozumu w sprawach publicznych, a realizując to zadanie, staje się integralną częścią „wspólnoty światowej” czytającej i rozprawiającej publiczności. Publiczne nauczanie ludu należałoby jednak powierzyć niezależnym nauczycielom, właśnie filozofom, którzy mogliby w ten sposób sprzyjać postępowi ku najwyższemu dobru na Ziemi. Dlatego też ograniczenie swobody publicznego nauczania, możliwości kształtowania opinii obywateli gotowych podjąć trud oświecenia stanowi poważne zagrożenie dla postępu - jak stwierdza Kant: „Zatem zakaz jawności hamuje postęp narodu ku lepszemu"24.

Zatrzymaliśmy się dłużej przy problematyce „publicznego użytku z rozumu", ponieważ specyficznie pojmowana przez Kanta sfera publiczna nie tylko służy zbiorowemu oświeceniu, nie tylko zgłasza weto wobec nadużyć rządzących i piętnuje patologie systemu prawnego, ale również pośredniczy pomiędzy głosem ludu, który doświadcza niesprawiedliwości i domaga się zmiany politycznej a reżymem panującej władzy. Rewolucja francuska napędzana społecznym niezadowoleniem, krzywdą uciśnionego ludu nie miała

\footnotetext{
${ }^{23}$ I. Kant, Odpowiedź na pytanie..., dz. cyt., s. 49.

${ }^{24}$ I. Kant, Spór fakultetów..., dz. cyt., s. 264.
} 
ani cierpliwości, ani zaufania wobec deliberującej, oświeconej publiczności, która mogłaby utrzymać buntownicze impulsy w ryzach prawa. Jednakże rewolucjoniści, choć działali pod dyktatem „wybuchowych” emocji, bezwiednie odsłonili idee, które z perspektywy publicznie rezonującego rozumu mają nieocenioną wartość. Być może słuszna jest w tym kontekście uwaga Arendt, że potępienie przez Kanta rewolucji polegało na nieporozumieniu - na błędnym utożsamieniu rewolucji z zamachem stanu, który odbywa się w ukryciu i zaprzecza jawności. Pewne ustępy z eseju Ku wieczystemu pokojowi $i^{25}$ zdają się potwierdzać jej przypuszczenie, jednak nawet jeśli zgodzimy się $\mathrm{z}$ taką interpretacją, nie zmieni to zasadniczo faktu, że rewolucja unicestwiła w brutalny sposób panujący porząadek prawa i fundującą go konstytucję, a zatem w żadnym wypadku nie mogła uzyskać moralnej aprobaty ze strony królewieckiego filozofa. Jego entuzjazm wobec niej nie dotyczył bowiem samych wydarzeń, faktycznych działań, lecz ich głębokiego sensu, który stał się widoczny dopiero z perspektywy niezaangażowanego, bezstronnego widza - oświeconej publiczności. Jak stwierdza Kant:

Wydarzenie to nie polega bynajmniej na dokonanych przez ludzi ważnych czynach lub zbrodniach, w wyniku których to, co dla ludzi wielkie staje się małe, to zaś co małe wielkie. Nie dotyczy również dawnych imponujących gmachów państwa, które znikają jak pod wpływem czarów, zaś w ich miejsce jak spod ziemi wyrastają inne. Nie - nic z tych rzeczy ${ }^{26}$.

Autor Sporu fakultetów proponuje nam zatem intrygującą perspektywę spojrzenia na rewolucję, w której z pola widzenia znikają bezprzykładne zbrodnie i terror Jakobinów, w której nasza uwaga nie zatrzymuje się na rewolucyjnym delirium, lecz uchwytuje ulotny sens rewolucji jako „znaku dziejowego". Sygnałem rozpoznawczym owego niepowtarzalnego wydarzenia jest to, że towarzyszył mu entuzjazm będący reakcją niezaangażowanych obserwatorów. Zdaniem Kanta nie ma on wcale związku z tym, czy rewolucja powiodła się, czy nie, ani z ewentualnymi realnymi możliwościami, które otwierała przed jej uczestnikami. Nie chodzi też o to, że entuzjazm aktywizuje widzów, ponieważ w istocie polega on na uczuciu biernego współuczestnictwa, które ma charakter dobrowolny i nie wynika z jakichś partykularnych interesów:

\footnotetext{
${ }^{25}$ Por. I. Kant, Ku wieczystemu pokojowi..., dz. cyt., s. 370 i. nn.

${ }^{26}$ I. Kant, Spór fakultetów..., dz. cyt., s. 260.
} 
[...] prawdziwy entuzjazm zawsze odnosi się tylko do tego, co idealne, a nawet czysto moralne, jak pojęcie prawa i nie da się go użyć do korzyści własnej. Nagrodami pieniężnymi nie dałoby się skłonić przeciwników rewolucji, by wykazali się żarliwością i wielkodusznością $[\ldots]^{27}$.

Owym idealnym sensem odkrywanym z dystansu przez oświeconą publiczność jest, z jednej strony, idea postępu ludzkości - obietnica, jaką przynosi rewolucja nadchodzącym pokoleniom, a $\mathrm{z}$ drugiej - nieprzedstawialna z natury idea wolności.

\section{Entuzjazm i rewolucja}

Kant opisuje rewolucję jako wzniosłe wydarzenie, jako swoisty dziejowy dramat rozgrywający się na scenie politycznego theatrum. Najważniejsza w całym spektaklu jest wspomniana już entuzjastyczna reakcja widzów, bez której rewolucja rozpadłaby się na szereg niepowiązanych ze sobą wydarzeń i działań, a tym samym zniknęłaby z ludzkiej pamięci. Działający czy „gracze" - jak pisze Kant - lub aktorzy nie są w stanie uchwycić znaczenia swojego działania, tworzą zatem idealny sens, choć go sobie nie uświadamiają. Ta zaskakująca prawidłowość ma tę zaletę, że uczestnicy spektaklu zaangażowani bądź co bądź w skomplikowane, absorbujące działania zostają w ten sposób odciążeni od konieczności podejmowania żmudnej refleksji, która mogłaby tylko osłabić siłę ich motywacji. Widownia zaś rozpoznaje i ocenia sens dramatycznych działań, chociaż w nich nie uczestniczy. Ważne przy tym jest to, że wgląd w ideę ujawniającą się w rewolucyjnym spektaklu nie determinuje w najmniejszym stopniu konkretnej praxis, nie ma żadnego znaczenia dla zasad działania.

Teatralna metaforyka zastosowana przez Kanta uwypukla ponadto fakt, że „widz” musi zająć odpowiednie miejsce, które umożliwi mu wzniesienie się ponad przypadkowość obserwowanych faktówi w ostatecznym rozrachunku - pozwoli mu ujrzeć w synoptycznym spojrzeniu całość „wydarzenia”. Aktor stanowi natomiast część przedstawienia i musi, chcąc nie chcąc, odgrywać swoją rolę, dlatego zawsze pozostaje stronniczy. Widz przeciwnie, zajmuje bezstronną postawę niezaangażowanego obserwatora, nie ma żadnej przypi-

27 Tamże, s. 261. 
sanej mu odgórnie roli w historycznym przedstawieniu. To ważny moment, ponieważ według Kanta wycofanie się $\mathrm{z}$ bezpośredniego zaangażowania na neutralne stanowisko stanowi warunek sine qua non poprawnego użycia władzy sądzenia. W omawianym przypadku sądzenie staje się integralną częścią czegoś, co moglibyśmy nazwać historiozoficzną hermeneutyką Kanta - sztuką rozumienia niejawnego sensu procesu dziejowego. Znaczenie rewolucji ukazuje tutaj historia jako pewna opowieść, a zatem nie jako zbiór faktów, dat, archiwalnych dokumentów, ale właśnie jako szczególnego rodzaju narracja wyrażona $\mathrm{w}$ języku oświeconej publiczności. Fakty są $\mathrm{z}$ natury nieme, pojawiają się i znikają bezpowrotnie, jeśli nie towarzyszy im język. Podobnie rozumieli historię Starożytni z tą jednak różnicą, że znaczenie historii ujawniało się, według nich, dopiero wówczas, gdy dobiegła ona końca, natomiast dziejowe znaczenie rewolucji polega, według Kanta, na tym, że budzi ona nadzieję na przyszłość, że jej właściwy sens dopiero się ujawni - a zatem nawet wówczas, gdy uzyskamy czasowy dystans, gdy będziemy spoglądać na nią jak na zamknięte, odsunięte w przeszłość zdarzenie, nie uchwycimy jej sensu jako czegoś dokonanego. Sens ten stanowi raczej rodzaj prospektywnej (zwróconej ku przyszłości) współrzędnej, która otwiera nieskończony horyzont rozumienia tego, czym jest postęp wolności, który dla Kanta nie ma końca.

W recenzji Myśli o filozofii dziejów J. G. Herdera Kant stwierdza, że ukryty cel przyrody polega na tym, by rozwinąć wszystkie predyspozycje, zadatki tkwiące w ludzkim gatunku. Proces ten jednak jest nieskończony, dlatego ludzkość może zbliżać się do tego celu jedynie asymptotycznie:

Jednak, jeżeli gatunek ludzki oznacza całość ciągnącego się ku temu, co nieskończone (niedające się określić) szeregu pokoleń (takie znaczenie jest bowiem powszechnie uznane) i jeśli przyjmie się, że ten szereg nieustannie zbliża się do linii swego celu, wówczas nie ma żadnej sprzeczności w twierdzeniu, że jest ona asymptotyczna do niej we wszystkich swych częściach i w całości się z nią zgadza, innymi słowy, że nie pojedynczy element wszystkich pokoleń ludzkiego rodzaju, a tylko gatunek w pełni osiąga swoje przeznaczenie ${ }^{28}$.

W perspektywie historiozoficznej Kanta widz rewolucji nie jest tylko neutralnym sędzią zasiadającym w trybunale światłej publiczności, ale staje się zarazem „obywatelem świata”, a raczej „obserwatorem świata”. Mając przed sobą wyobrażenie całości, decyduje, czy dane wydarzenie odsyła

${ }^{28}$ I. Kant, Recenzje „Myśli o filozofii dziejów” J.G. Herdera, t. VI, s. 75-76. 
do idei wolności, czy nie. Tego rodzaju osądowi musi jednak towarzyszyć wspomniany entuzjazm, a ściślej „uczucie współuczestnictwa graniczące $\mathrm{z}$ entuzjazmem"29.

Zanim wyjaśnimy właściwe znaczenie tego afektu w konstrukcji teoretycznej Kanta, powinniśmy podkreślić, że nie należy go w żadnym wypadku utożsamiać z impulsywnym zachwytem, ani tym bardziej z fanatyczną, quasi-instynktowną reakcją tłumu. Entuzjazm oświeconej widowni nie prowadzi do jej odpolitycznienia, do estetyzacji polityki, wręcz przeciwnie - konstytuuje on przestrzeń politycznej wolności. Nie chodzi więc o afektywne, cielesne pobudzenie, lecz bardziej o stan ducha:

Wszystko to jest wyłącznie efektem sposobu myślenia obserwatorów - który w tej grze wielkich przemian objawia się publicznie i uzewnętrznia się jako powszechna, chociaż bezinteresowna sympatia dla graczy, z jednej strony a przeciwko drugiej, nawet przy zagrożeniu, że owa stronniczość raz odkryta okazać się może bardzo niekorzystna. Jednakże (z powodu powszechności) dowodzi to jaki jest charakter ludzkiego rodzaju w całości, a jednocześnie (z powodu bezinteresowności), jaki jest moralny charakter ludzkości przynajmniej w jej predyspozycjach. Charakter ten nie tylko pozwala żywić nadzieję na postęp, lecz sam już nim jest ${ }^{30}$.

Postawa widowni nie tworzy zatem spektaklu opartego na żądzy mocnych wrażeń, na rozkoszowaniu się obrazem nieszczęść i rozlewu krwi, nie chodzi tutaj o bierną aklamację, o bezkrytyczne afirmowanie wydarzeń politycznych, ani o dreszcz grozy, jaki umożliwia zajmowanie zdystansowanej, bezpiecznej pozycji wobec obserwowanych zjawisk, czy też o neutralizujące lęk „sycenie się" widokiem katastrofy, o którym pisał Lukrecjusz w swoim poemacie $O$ naturze wszechrzeczy $y^{31}$.

Gdyby entuzjazm wywołany rewolucją płynął z opisanych powyżej pobudek, reakcja oświeconej widowni zamieniłaby się w jałowy spektakl, który

\footnotetext{
${ }^{29}$ I. Kant, Spór fakultetów..., dz. cyt., s. 260.

30 Tamże.

${ }^{31} \mathrm{~W}$ prologu do drugiej księgi tego dzieła rzymski filozof pokazuje filozofa kontemplującego świat jako człowieka, który stoi spokojnie na skale i przygląda się katastrofie okrętu, nie rozkoszując się wprawdzie zgubą, ale ciesząc się, że znajduje się w oddaleniu: „Miło w czas burzy morskiej, gdy życia sam nie narażasz. Patrzeć z brzegu na trudy wichrem gnanego żeglarza [...] Miło tę walkę walkę mężów oglądać w wielkich bojach, gdy z daleka bezpieczna całość i wolność twoja." Titus Lucretius Carus, O naturze wszechrzeczy, tłum. E. Szymański, Warszawa 1957, s. 42.
} 
paraliżuje wszelką polityczną inicjatywę, uniemożliwia dokonywanie realnych zmian w sferze politycznej i egzystencjalnej - dokładnie w taki sposób, jak opisał to Guy Debord w słynnej książce Społeczeństwo spektaklu $u^{32}$.

Rewolucja jest dla królewieckiego filozofa fałszywa i godna potępienia z perspektywy prawno-moralnej, choć zarazem słuszna z perspektywy politycznej. Sąd moralny i sąd polityczny odnoszą się bowiem do różnych pojęć wolności. W ocenie rewolucji nie możemy opierać się na zwodniczej zasadzie "cel uświęca środki”, dlatego nie da się moralnie uzasadnić rewolucji. W tym punkcie sąd polityczny towarzyszący odczuciu entuzjazmu zbliża się do specyficznego sądu estetycznego, jaki Kant odnosi do wojny. W Krytyce władzy sądzenia filozof stwierdza:

Nawet wojna, jeśli prowadzona jest $\mathrm{z}$ zachowaniem porządku i poszanowania praw obywatelskich, ma w sobie coś wzniosłego, przy czym charakter narodu, który wiedzie ją w ten sposób, czyni ją tym wznioślejszą, im liczniejsze były niebezpieczeństwa, na jakie był narażony i mimo których zdołał mężnie przetrwać. Natomiast długotrwały pokój zazwyczaj prowadzi do panowania samego tylko ducha handlu, a wraz z nim do niskiej chciwości, tchórzostwa i zniewieściałości oraz do zaniżenia się sposobu myślenia narodu ${ }^{33}$.

Wojna widziana $\mathrm{z}$ estetycznej perspektywy niezaangażowanego obserwatora może zatem kryć w sobie coś wzniosłego, ponieważ wyzwala w ludziach męstwo, odwagę, kreatywność, wytrąca ich z gnuśności i błogiego samozadowolenia, a przez to sprzyja ogólnemu rozwojowi (wojna jako „bicz ludzkiego rodu"34). Jednakże tego rodzaju sąd refleksywny dotyczący wojny nie niesie ze sobą żadnych praktycznych skutków dla działania. Jeśli chodzi bowiem o działanie, to nie ma wątpliwości, że „[...] nasz moralny rozum praktyczny zgłasza swoje nieodparte weto: nie powinno być żadnej wojny"35. W dziedzinie polityki nadrzędną zasadą działania powinno być dążenie do pokoju, natomiast kierowanie się wiedzą o „zbawiennych” skutkach wojny, której dostarcza sąd estetyczny, czyni polityka zwykłym przestępcą. Jednakże - takie

32 Według Deborda, współczesna polityka, a w zasadzie cała kultura została zdegradowana do quasi-estetycznego spektaklu, który nieustannie wytwarza w odbiorcach stan pobudzenia, chwilowej ekscytacji tylko po to, by utrwalić rozdział pomiędzy działaniem a biernym oglądem, a tym samym, by zdławić w zarodku wszelki opór, krytyczne myślenie i chęć dokonania zmiany. Por. G. Debord, Społeczeństwo spektaklu, tłum. M. Kwaterko, Warszawa 2006.

${ }^{33}$ I. Kant, Krytyka władzy sadzenia..., dz. cyt., s. 137.

${ }^{34}$ Tenże, Religia w obrębie samego rozumu, t. V, s. 37.

${ }^{35}$ Tenże, Metafizyka moralności..., dz. cyt., s. 458. 
jest chyba przesłanie Kanta - owej brutalnej, „estetycznej wiedzy” nie da się po prostu zapomnieć, dlatego towarzyszy ona nawet najbardziej pokojowo nastawionej polityce. Wiedza ta, choć nie można jej praktycznie zastosować, daje nam bardziej wyważony, realistyczny osąd sytuacji, chroni nas przed pacyfistycznym idealizmem, który właśnie z powodu swojego braku realizmu może stać się niebezpieczny.

Podobną ambiwalencję opisuje Kant w swojej rozprawce Przypuszczalny początek ludzkiej historii na przykładzie alegorii grzechu pierworodnego, który w aspekcie moralnym był upadkiem, złem, ale w perspektywie rozwoju gatunku ludzkiego nie był „[...] niczym innym jak przejściem od nieokrzesania istoty czysto zwierzęcej do człowieczeństwa, od zniewolenia przez instynkt do kierownictwa rozumu, jednym słowem, od opieki natury do stanu wolności”36.

Również entuzjastyczny obserwator rewolucji dostrzega w niej zamiar, ukrytą celowość przyrody, „[...] każącą ludziom poprzez waśnie, nawet wbrew ich woli, wznieść się do zgody"37 - a zatem realizować ideę wolności i dążyć do wieczystego pokoju. Tym właśnie entuzjasta różni się od „entuzjastycznego fanatyka", który nie opiera się na władzy sądzenia i nie rozumie właściwego sensu porywającego go wydarzenia. W przypadku rewolucji francuskiej widzowie zostali zatem, według Kanta, skonfrontowani z ideą wolności niezależnie od tego, czy szukali jakiejś innej racji determinującej tę ideę poza prawem moralnym, czy nie. W kontekście pojęcia entuzjazmu najważniejsze jest założenie, że ich postawę określiło nie tyle samo uczucie (euforyczna akceptacja), ile powiązany z nim sąd - nazwijmy go „sądem entuzjastycznym”. Wspomnieliśmy już, że jego struktura przywodzi na myśl refleksyjny sąd smaku. Zanim przejdziemy do omówienia tej analogii, dla jasności odróżnijmy go od dwóch typów sądów, których często używa się w opisie procesów historycznych.

Po pierwsze, należy go odróżnić od sądu determinującego, ponieważ tego rodzaju sąd oceniałby rewolucję na podstawie znanych pojęć i teorii, podczas gdy rewolucja $z$ natury jest czymś nowym, niepowtarzalnym, dlatego nie dającym się określić. Opis rewolucji w świetle pewnych znanych - czy lepiej uznanych - w dyskursie naukowym prawidłowości historycznych, socjologicznych, ekonomicznych, obyczajowych etc. może ewentualnie nastąpić dopiero w przyszłości, jednakże nawet wówczas nie zbliży nas do uchwycenia jej

\footnotetext{
${ }^{36}$ I. Kant, Przypuszczalny początek ludzkiej historii..., dz. cyt., s. 124.

${ }^{37}$ Tenże, Ku wieczystemu pokojowi..., dz. cyt., s. 350.
} 
właściwego sensu. Po drugie, entuzjastyczny sąd nie jest również arbitralną opinią wynikającą z przypadkowych pobudek, indywidualnych preferencji wydającego go podmiotu. Nie dotyczy on bowiem jednego $\mathrm{z}$ wielu faktów, lecz kieruje się ku uniwersalnej, choć nieprzedstawialnej idei wolności.

Rewolucja pomimo to, że jest wydarzeniem o charakterze historycznym (a zatem zbiorowym), przypomina jednostkowy akt wolności w tym sensie, że w swojej istocie nie jest uwarunkowana wyłącznie przyczynowo, lecz stanowi wyraz wolności, która samodzielnie wyznacza swój własny przebieg ${ }^{38}$, a tym samym otwiera całkiem nowy łańcuch zdarzeń. Innymi słowy, rewolucja przerywa przyczynowy łańcuch działań zdominowanych przez walkę o władzę, przez dążenie do zaspokojenia partykularnych interesów. Rewolucyjny zryw przecina nici łączące teraźniejszość z przeszłością (ze starym porządkiem), nie jest więc - na poziomie transcendentalnym, jeśli można się tak wyrazić - kolejnym ogniwem, kontynuacją poprzedzających go wydarzeń. Oczywiście rewolucja nie pojawia się nigdy jak deus ex machina, znikąd, ale też nie da się jej opisać jako rezultatu dziejowej konieczności. Wprawdzie w wymiarze empirycznym bez trudu można wskazać szereg uwarunkowań, które doprowadziły do jej wybuchu, jednakże ta perspektywa opisu jest dla Kanta nieistotna w kontekście entuzjastycznej reakcji oświeconej widowni.

Trzymając się metaforyki teatralnej, możemy powiedzieć, że „wykonawcami” rewolucyjnego spektaklu są konkretni aktorzy zaangażowani w realne działania, a „reżyserem” tego przedstawienia jest „opatrzność” realizująca swój ukryty cel w skali gatunku ludzkiego, czy też przeznaczenie „[...] jako determinująca przyczyna, której prawa oddziaływania nie są nam znane"39. Jeśli rewolucja powołuje do życia coś radykalnie nowego, to wiąże się z tym również fakt, że novum to pozostaje niezrozumiałe dla samych rewolucjonistów - bez wątpienia działający aktorzy kierują się określonymi (zazwyczaj partykularnymi) ideami, ale rodzący się niejako na ich oczach (i poprzez ich czyny) sens „wydarzenia” pozostaje przed nimi ukryty, nie daje się w żaden sposób wyartykułować. Rewolucjoniści działają w całkiem nowej sytuacji, która nie miała precedensu w historii, nie mogą zatem wyprowadzić zasad swojego postępowania $\mathrm{z}$ istniejącej praktyki, ponieważ zasady te nie zostały jeszcze sformułowane. Siłą rzeczy zmuszeni są działać „na ślepo”. Rewolucja jako akt założycielski in statu nascendi pokazuje tylko tyle, że możliwe jest

\footnotetext{
${ }^{38}$ Por. rozważania Kanta na temat przyczynowości wolności, tj. idei bezwarunkowej wolności kierującej się prawem moralnym. I. Kant, Krytyka praktycznego rozumu, t. III, s. 178 i nn.

${ }^{39}$ Tamże, s. 350.
} 
zerwanie ze starym porządkiem. Jedynie widzowie potrafią dostrzec idealny wymiar przełomowej chwili. Moralna predyspozycja przejawia się bowiem w rewolucji jako to, co idealne - jak pisze Kant.

W tym kontekście nasuwa się jednak pytanie, jak można opisać sąd, który odnosi się do czegoś, co nie jest żadnym obiektem, a ku któremu mogłyby zwrócić się intencje działających? Poszukując podobnego pod względem struktury bezprzedmiotowego sądu w filozofii Kanta, bez trudu odnajdziemy go w analityce wzniosłości, gdzie pojawia się nawet wyraźna sugestia, że entuzjazm jest analogiczny do wzniosłości ze względu na to, że wywołują go idee, których nie można przedstawić. Wprawdzie Kant ma w tym kontekście na myśli ideę dobra, a nie wolności, ale możemy skorzystać z jego sugestii, gdyż chodzi nam wyłącznie o wspomniane strukturalne podobieństwo. Fragment brzmi następująco:

Idea dobra łącząca się z afektem zwie się entuzjazmem. Ten stan umysłu wydaje się być tak dalece wzniosły, że zwykle powiada się, iż bez niego niczego wielkiego nie da się dokonać. Ale każdy afekt jest ślepy albo w wyborze swego celu, albo jeśli cel został również dany przez rozum, w jego realizacji. [...] Lecz estetycznie entuzjazm jest mimo wszystko wzniosły, bo polega na napięciu sił przez idee, które nadają umysłowi rozmach oddziałujący o wiele mocniej i trwalej aniżeli pobudzanie za pośrednictwem wyobrażeń zmysłowych ${ }^{40}$.

Nie mamy miejsca na analizę szerszego kontekstu tego ustępu, więc wykorzystamy go jedynie jako podstawę do wskazania kilku ogólnych analogii między entuzjazmem a wzniosłością, zwłaszcza dynamiczną. Według Kanta wzniosłość dynamiczna nie jest cechą przedmiotu empirycznego, lecz odczuciem podmiotu, które zostało wywołane przez zjawiska, nie dające się wyobrazić w formie jakiejkolwiek określonej wielkości. Filozof podaje w tym kontekście głównie przykłady wzniosłości występującej w przyrodzie (sztorm, strzeliste skały, wybuch wulkanu, etc.), ale oczywiście uczucie to może być wywołane również przez zjawiska związane z aktywnością człowieka, o ile tylko stanowią one przejaw mocy, która wzbudza w nas lęk. Jak komentuje Żelazny: „[...] jest to wrażenie najczystsze z możliwych: wywołane przez samą tylko dynamikę zjawiska, właściwie bez żadnego wymiernego udziału czynników geometrycznych”41. Konfrontacja z zagrażającą nam „po-

\footnotetext{
${ }^{40}$ I. Kant, Krytyka władzy sądzenia..., dz. cyt., s. 147.

${ }^{41}$ M. Żelazny, Źródłowy sens pojęcia estetyka. Rozprawy z historii estetyki niemieckiej, Toruń 1994, s. 61.
} 
tęgą" wywołuje w nas wstrząs, lęk i „odpływ sił witalnych”, któremu musimy następnie stawić opór. Jest to możliwe tylko wówczas, gdy znajdujemy się w bezpiecznym miejscu.

Lecz widok [tych potęg] jest tym bardziej pociągający, im większy budzi lęk, jeśli tylko my sami znajdujemy się w bezpiecznym miejscu. Dlatego też takie przedmioty chętnie nazywamy wzniosłymi, bo podnoszą siłę naszej duszy ponad jej zwyczajną, przeciętną miarę i pozwalają nam odkryć w sobie zupełnie innego rodzaju zdolność do stawiania oporu, która daje nam odwagę do tego, by mierzyć się z pozorną wszechmocą przyrody ${ }^{42}$.

W tej sytuacji wprawdzie odczuwamy wyraźnie, że nie możemy jako istoty empiryczne przeciwstawić się przemożnej potędze, ale zarazem uświadamiamy sobie, że jako istoty obdarzone rozumem i autonomią możemy osądzać samych siebie niezależnie od przyrody i ogarniających nas emocji. Kant opisuje to odczucie jako „entuzjastyczne upodobanie” i podkreśla, że może ono pojawić się tylko wówczas, gdy dysponujemy moralnymi ideami.

Przedstawiona powyżej szkicowa charakterystyka wzniosłości dynamicznej wskazuje wyraźnie strukturalne podobieństwa $\mathrm{z}$ naturą entuzjazmu politycznego. Po pierwsze, entuzjazm podobnie jak wzniosłość nie odnosi się do jakiegoś przedmiotu, lecz do pewnego stanu umysłu. Po drugie, obydwa uczucia mają ambiwalentny charakter, ponieważ łączą w sobie doznanie przykrości i rozkoszy, odpływu i przypływu sił. Widownia przyglądająca się z dystansu rewolucyjnemu spektaklowi doświadcza, z jednej strony, odczucia grozy, jaką wywołuje gwałtowność i destrukcyjność konkretnych, empirycznych wydarzeń, z drugiej zaś strony, przeżywa bezinteresowną rozkosz płynącą z rozpoznania przebłysku idei wolności, obietnicy postępu ludzkości. Po trzecie wreszcie, zarówno w stanie entuzjazmu, jak i w uczuciu wzniosłości umysł nie potrafi bezpośrednio ująć idei wolności, ale mimo to jest do niej negatywnie odniesiony za pośrednictwem oporu, jaki stawia lękowi wywołanemu przez niemierzalną moc. Ponadto polityczny entuzjazm (podobnie jak wzniosłość) nie jest afektem, który dołączałby się tylko do pewnego (estetycznego bądź politycznego) sądu, lecz należy go raczej rozumieć jako szczególnego rodzaju afektywne ukierunkowanie władz umysłowych pobudzonych przez ideę rozumu. Albo inaczej - jest czystym afektem, w którym

${ }^{42}$ I. Kant, Krytyka władzy sq̨dzenia..., dz. cyt., s. 135-136. 
rozum ujawnia się ex negativo $\mathrm{w}$ formie szczególnego typu sądu refleksywnego.

Pod pewnym względem entuzjazm wykazuje również podobieństwo do szacunku (Achtung) wobec prawa powszechnego. Po pierwsze, szacunek jest czystym afektem, który nie odnosi się do żadnego przedmiotu, ponieważ pozbawione treści prawo moralne determinuje wolę do działania wyłącznie pod względem formy. Po drugie, szacunek podobnie jak entuzjazm (i wzniosłość) jest afektem dwustopniowym w tym sensie, że łączy w sobie „odczucie przykrości” - prawo zmusza mnie do porzucenia skłonności, zmysłowych pobudek oraz „odczucie rozkoszy” - rezygnacja z egoistycznej motywacji uwalnia mnie jako moralny podmiot, to znaczy pozwala mi doświadczyć prawdziwej wolności.

Podsumowując, możemy powiedzieć, że entuzjazm stanowi afektywne medium, w którym manifestuje się idea wolności. Pamiętać jednak należy, że nie ujawnia się ona w nim ani bezpośrednio - wówczas stałaby się symbolem, ani w postaci sądu determinującego. Entuzjastyczny sąd nie ma więc w zasadzie żadnej pojęciowej treści. Czyli np. stwierdzenie, że „w trakcie rewolucji zdobyto bastylię”, albo że „rewolucja przyczynia się do postępu rodzaju ludzkiego" w najmniejszym nawet stopniu nie wyczerpuje sensu entuzjastycznego sądu. Sąd ten jest na wskroś rozumowy, nie ocenia żadnych konkretnych rewolucyjnych czynów, wskazuje nam tylko, że mamy w tym przypadku do czynienia ze znakiem dziejowym. Tym samym entuzjazm pozbawiony jest wszelkiego empirycznego odniesienia, lecz wyraża szczególne nastawienie władz umysłowych widowni.

Na zakończenie naszych wywodów należałoby jeszcze omówić rolę entuzjazmu po stronie aktorów, czyli rzeczywistych uczestników rewolucji, którzy podejmując dalekosiężne $\mathrm{w}$ skutkach decyzje, $\mathrm{w}$ istocie nie byli w stanie przewidzieć ich skutków. Rewolucjonista nie ma żadnych sprawdzonych recept, wskazówek, na których mógłby oprzeć się w swoich prognozach. Jako człowiek czynu znajduje się więc w paradoksalnej sytuacji, w której nie może właściwie kalkulować w kategoriach środka i celu, nie może szukać gotowych racji, które uzasadniałyby jego wybory. Tym, co popycha go do heroizmu, jest bezinteresowny entuzjazm zastępujący hipotetyczne imperatywy działania. Rewolucjonista ogarnięty wzniosłym afektem walczy w imię idei wolności, której nie potrafi nawet wyartykułować, rzucając się w rewolucyjne piekło bez jakiejkolwiek wiedzy o tym, jaką rolę przyjdzie mu w nim odegrać. Odwaga - cnota polityczna par excellence staje się w ten sposób „pieczęcią" jego bezinteresowności, a zarazem pośrednim rezultatem oddziaływania idei wol- 
ności. Innymi słowy, nie jest tak, że w działaniu rewolucjonisty afekt zastępuje rozum, lecz raczej to sam rozum nasyca się afektem, ponieważ potrzebuje entuzjazmu nie tylko do sformułowania rozumnej oceny rewolucyjnego spektaklu, ale również do działania jego uczestników.

Zdolność do podejmowania bezwiednej aktywności w imię idei przywodzi nieuchronnie na myśl twórczość artysty obdarzonego geniuszem, o którym Kant pisze w Krytyce władzy sq̨dzenia:

Geniusz jest wrodzoną predyspozycją umysłu (ingenium), za pomocą której przyroda ustanawia reguły dla sztuki. [...] Widać stąd, że geniusz jest: 1) talentem tworzenia czegoś, na co nie można podać żadnej determinującej reguły, nie zaś dyspozycją zręczności do nauczenia się tego, czego można się wyuczyć zgodnie z jakąś regułą; pierwszą jego cechą musi zatem być oryginalność [...] 3) że [geniusz] sam nie może opisać ani naukowo wykazać, w jaki sposób tworzy swe dzieło, lecz że ustanawia reguły w imieniu natury [als Natur die Regel gebe], że zatem twórca, który dzieło zawdzięcza swemu geniuszowi, sam nie wie, skąd biorą się u niego idee owego dzieła ${ }^{43}$.

Rewolucjonista byłby zatem kimś w rodzaju politycznego geniusza, który znajduje wyraz dla idei nie tyle w artystycznym przedstawieniu, ile we własnym czynie. Istotne przy tym jest również to, że wyrażona przez niego w praktyczny sposób idea wywołuje ten sam entuzjastyczny stan umysłu u wszystkich „światłych” widzów. Zadanie politycznej i artystycznej genialności polegałoby więc na uczynieniu tego stanu umysłu zdolnym do powszechnego udzielania się. Komunikowalnością kieruje zaś władza sądzenia nie będąca wyłącznym przywilejem genialności, dlatego to dopiero sąd widza - oświeconej publiczności - tworzy przestrzeń, w której można ujawnić i zakomunikować ogólny sens ukryty w rewolucyjnym wydarzeniu.

Kończąc nasze analizy, chcielibyśmy uwypuklić ich najważniejszą - w naszym mniemaniu - konkluzję. Ambiwalentny stosunek Kanta do rewolucji francuskiej da się wyjaśnić wyłącznie na podstawie pojęcia entuzjazmu. To właśnie ten czysty, rozumowy afekt, który udziela się zarówno zdystansowanej, światłej publiczności, jak i zaangażowanym aktorom wytwarza polityczny charakter owego "ostatniego - jak pisze Kant - wydarzenia”. W przeciwieństwie zatem do Arendt, która uznaje, że główną przyczyną niepowodzenia rewolucji było wprzęgnięcie w nią „destrukcyjnej siły” afektów, Kant wskazuje, że nie tyle wyrozumowana, „chłodna” deliberacja, ile właśnie

${ }^{43}$ Tamże, s. $185-186$. 
entuzjazm nadał sens rewolucyjnym poczynaniom, a tym samym stał się nieodłącznym składnikiem stricte politycznego działania.

„Działanie rewolucyjne” nabiera bowiem charakteru politycznego dopiero w tym momencie, gdy na arenie publicznej wyłania się entuzjastyczny osąd obserwatorów. Polityczność działania oznaczałaby w tym ujęciu, że nie jest ono sumą jednostkowych uczynków, decyzji, lecz aktywnością mającą charakter publiczny, aktywnością, którą konstytuują teatralne ramy reagującej $z$ entuzjazmem widowni i porwanych entuzjazmem aktorów.

\section{Bibliografia}

Arendt H., Wykłady o filozofii politycznej Kanta, tłum. R. Kuczyński, M. Moskalewicz, Warszawa 2012.

Arendt H., Prawda i polityka, [w:] tenże, Między czasem minionym i przyszłym, tłum. M. Godyń, W. Madej, Warszawa 1994.

Debord G., Społeczeństwo spektaklu, tłum. M. Kwaterko, Warszawa 2006.

Kant I., Antropologia w ujęciu pragmatycznym, tłum. E. Drzazgowska, P. Sosnowska, Warszawa 2005.

Kant I., Dzieła zebrane, Wydanie Translatorium Filozofii Niemieckiej Instytutu Filozofii UMK, t. 1-6, Toruń: Wydawnictwo Naukowe Uniwersytetu Mikołaja Kopernika 2010-2014:

- Krytyka władzy sadzenia, t. IV.

- Metafizyka moralności, t. V.

- Spór fakultetów, t. V.

- Religia w obrębie samego rozumu, t. V.

- Ku wieczystemu pokojowi, t. VI.

- Odpowiedź na pytanie: czym jest oświecenie?, t. VI.

- Co oznacza: orientować się w myśleniu?, t. VI.

- Recenzje „Myśli o filozofii dziejów” J. G. Herdera, t. VI.

- Przypuszczalny początek ludzkiej historii, t. VI.

- O porzekadle: To może być stuszne $w$ teorii, ale nic nie jest warte $w$ praktyce, t. VI.

Titus Lucretius Carus, O naturze wszechrzeczy, tłum. E. Szymański, Warszawa 1957. 


\section{Abstract \\ Kant and the French Revolution. A Contribution to the Theory of Political Enthusiasm}

This article is an attempt to explicate the notion of political enthusiasm through which Immanuel Kant expressed his attitude to the French Revolution. Enthusiasm as a purely rational affect, not as a collectively experienced, irrational euphoria, functions in the Kant's deliberations an important heuristic function because it allows him to justify the positive meaning of the revolution, which at the level of empirical facts turned out to be an escalation of violence. The first section outlines the definition of politics that will be useful in the further analysis of the category of enthusiasm. The main point of reference here is Hannah Arendt's political theory. In the second part I attempt to clarify the ambiguous attitude of Kant to the French Revolution, which from the moral perspective was unequivocally condemned by him, and from the aesthetic and political perspective - evaluated very favorably. The key to understand this ambivalence is the category of publicity (Publizität). In the third section I move to the main theme of the article, i.e. the issues of enthusiasm in a political context.

Key words: revolution, politics, enthusiasm, public sphere, judgment, sublime, Immanuel Kant, Hannah Arendt 